\title{
SEROPREVALENCE OF ANTIBODIES TO VENEZUELAN EQUINE ENCEPHALITIS COMPLEX (SUBTYPES IAB AND VI) IN HUMANS FROM GENERAL BELGRANO ISLAND, FORMOSA, ARGENTINA
}

\author{
Alicia CÁMARA(1), Gladis DÍAZ(1), Victor VEGA(1), María BASUALDO(2) \& Marta CONTIGIANI(1)
}

\begin{abstract}
SUMMARY
This work presents the results of the detection of antibodies (immunoglobulin G) for subtypes I and VI of VEE viruses complex (Togaviridae family) in people from the General Belgrano island, Formosa province (Argentina). The prevalence of neutralizing (NT) antibodies for subtype VI was from $30 \%$ to $70 \%$ and the prevalence of antibodies inhibitory of hemagglutination (HI) was of $0 \%$ in the first and second inquiry respectively. For the subtype IAB the prevalence of NT antibodies was from $13 \%$ to $3.6 \%$, similar to the prevalence total for both subtypes. HI antibodies were not detected in any inquiries for any subtype. It was observed that both subtypes circulate simultaneously, while subtype VI remains constant with some peaks, subtype I was found in low level.
\end{abstract}

KEYWORDS: Alphavirus; Togaviridae; VEE; Seroprevalence; Humans; Argentina.

\section{INTRODUCTION}

Venezuelan equine encephalitis viruses (VEEV) are arthropod-borne, Western Hemisphere alphaviruses in the family Togaviridae. The VEE antigenic complex currently consists of six subtypes (I- VI). Subtype I is divided into five varieties (IAB, IC, ID, IE, IF), and subtype III is divided into three varieties (IIIA, IIIB, IIIC) (CALISHER et al., 1985 and 1988). The first two varieties of subtype $I(A B, C)$ are considered epizootic and epidemic on the basis of epidemiological evidences and experimental infections, being the other varieties (D, E and F) enzootic and endemic (WORK, 1964; EHRENKRANZ \& VENTURA, 1974).

VEE viruses produce infections in humans, which range from indifferentiated acute febrile diseases to slight and serious encephalitis, in less proportion (CALISHER, 1994). The varieties AB and C (subtype I) were the agents in epizootic equine disease that occurred for almost twenty years in Central and South America. Human cases were sporadically informed.

In general, epizootic varieties cause serious disorders in medical and veterinary conditions. Consequently it also causes economical and labor detriments (CALISHER, 1994).

IVERSSON et al. (1990), informed about an outbreak of the disease in humans in Ribeira Valley (São Paulo, Brazil), caused by subtype enzootic I F. Between 1993 and 1995 VEEV produced the most serious human infections in Colombia, Mexico and Venezuela, where enzootic subtypes IC and ID were isolated with high mortality among infected individuals. Simultaneously isolations and identifications in equines of subtypes epizootics and enzootics IAB, IC, ID and IE, (RIVERA et al., 1995) were described.

Recent equine outbreaks in southern Mexico with 40-50\% casefatality rates yielded subtype IE strains (OBERSTE et al., 1998). The close genetic relationship between the 1992-1993 IC viruses and enzootic ID strains from the nearby Catatumbo region of northern South America provides a model for the emergence of epidemic/epizootic VEE. In this model, enzootic ID viruses undergo one or more critical mutations that enhance equine viremia and virulence. The infrequency of epizootic VEE emergence and the high mutation frequencies exhibited by RNA viruses, including alphaviruses, suggest that an infrequent combination of several mutation leads to emergence (WEAVER, 1998). This finding show an epidemiological point of view, this behavior makes the separating line among enzootic and epizootic subtypes less sharp.

In Argentina, BETTINOTTI (1957) made the first seroepidemiological reports. He clearly demonstrated the activity of VEEV in Chaco and Corrientes provinces, with a prevalence of 50\%. In 1980, 19 strains of subtype VI (enzootic) were isolated from mosquitoes collected in Chaco province (MITCHELL et al., 1985). Later, antibodies to subtypes I AB and VI were detected in birds, rodents and equines (MONATH, 1980).

The prevalence of antibodies against VEE-subtype IAB, strain TC83 and subtype VI was reported in patients with acute febrile outbreak in 1989, at General Belgrano island of the Paraná river, Formosa province (CONTIGIANI et al., 1993).

(1) Instituto de Virología "J.M. Vanella”. Facultad de Medicina. Universidad Nacional de Córdoba, Argentina.

(2) Servicio Provincial de Chagas. Formosa, Argentina.

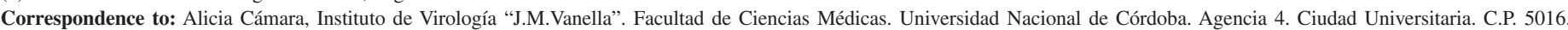
Córdoba. Argentina. Tel/fax: 54-51 680198. e-mail: virolog@cmefcm.uncor.edu. 


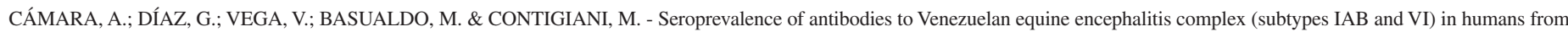
General Belgrano Island, Formosa, Argentina. Rev. Inst. Med. trop. S. Paulo 45(4): 201-204, 2003.

This work presents the results of a seroprevalence study for VEE subtypes IAB and VI on the population of the island General Belgrano during 1991.

\section{MATERIALS AND METHODS}

Study area and human sera: The area of the Parana river of Formosa province, Argentina, is covered with tropical rain forest with diverse flora and fauna. Climatic conditions are mild, at the north-east of the province is dry and the rest has 800 a $1000 \mathrm{~mm}$ precipitations per year. Mean annual temperature is $22-24{ }^{\circ} \mathrm{C}$. There is one season with higher temperature in December-January and lower in May-August.

Sera were collected from the General Belgrano little island (Fig. 1) inhabitants obtained by the Servicio Provincial de Chagas during 1991. Human main activity is farming which produces corn and citrus fruits. Thirty families live in the island (population: 150).

The first sera samples were 23 in total, and were taken in May from the school community where the 1989 outbreak took place. Fifteen persons were between 4-16 year-old with an even gender distribution; and 8 people were $24-50$ year-old. All attended at the local school facility. Two of these samples had been studied during the outbreak in 1989 and were retested in 1991. The tendency distributions sexual near of $90 \%$ toward female.

On the basis of the prevalence results obtained from the pilot test carried out in this study, the size of the minimal sample was calculated for an error of $10 \%$, which was $\mathrm{n}=33$, using the methods described by RAMIREZ et al., 1990.

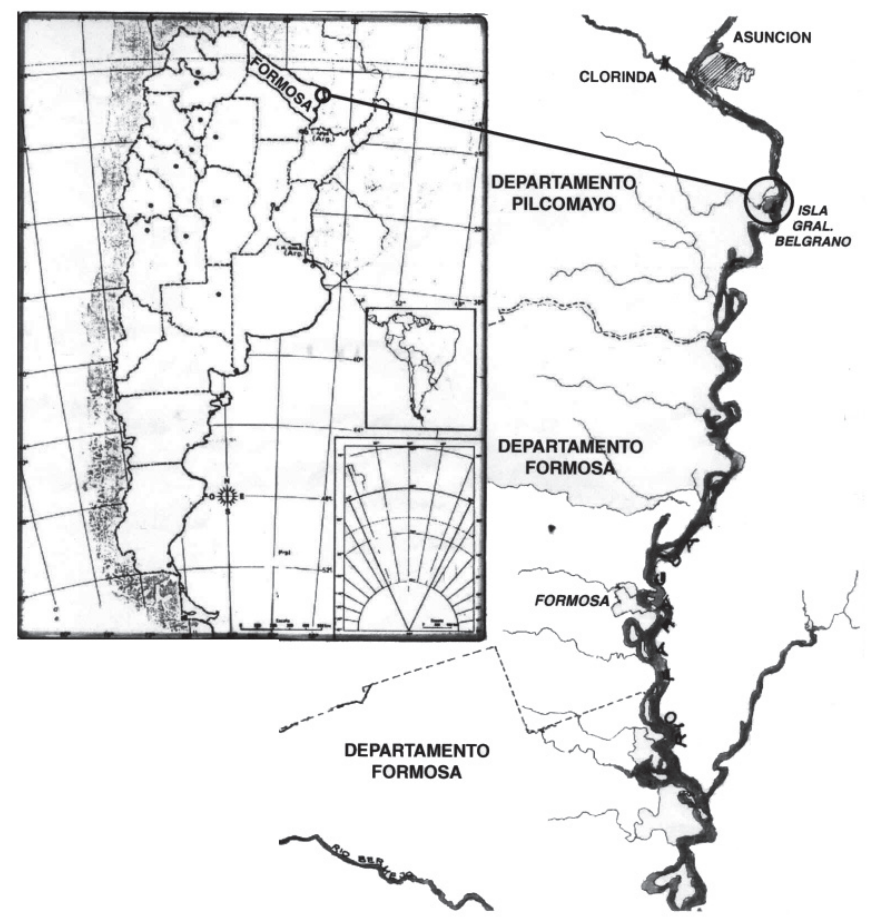

Fig. 1 - Map of General Belgrano Island, Formosa province, Argentina.
Later, 33 samples were received from the second collection in November 1991. This group had 19 individuals 3-20 year-old and 14 adults. None of them belonged to the previous study of May. The tendency distributions sexual near of $70 \%$ toward female.

The sera were maintained at $-20{ }^{\circ} \mathrm{C}$ until they were tested.

Viral strains: Two viral strains of VEE complex were used:

- Strain TC-83: vaccine strain derived from Trinidad donkey (TRD virus), subtype IAB, with 83 passages in guinea pig heart tissue culture (BERGE et al., 1961).

- Strain AG 80-663: enzootic strain with low pathogenesis for equines and unknown for humans, isolated from mosquito Culex (Melanoconion) delpontei in Argentina, 1980 (CALISHER et al., 1985).

Serological test: The detection and titration of specific antibodies were carried out by Hemagglutination Inhibition Test (HI) (CLARKE \& CASALS, 1958) and Neutralization Test (NT) using a method of quantification plaques forming units (EARLY et al., 1967).

The sera problem and normal mouse ascitic fluid (NMAF) for HI were previously acetone extracted, to eliminate unspecific inhibitors and then adsorbed by red blood cells of adults white domestic goose (Anser cinereus) to remove the agglutinins. The NMAF were used as negative controls and the hyperimmune mouse ascitic fluids (HMAF) obtained for each strain were used as positive controls, according to TIKASINGH et al. (1966).Viral antigens used for HI test, were prepared following the methodology of CLARKE \& CASALS (1958). Four-eight units were

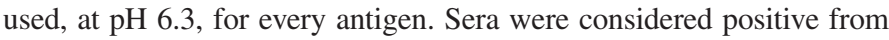
dilutions 1:20.

For NT, Vero Cl 76 cell line was used, cultured in Minimum Essential Medium (MEM) enriched with non essential aminoacids with $10 \%$ of fetal calf serum (FCS) and gentamicine. Monolayers of 24-48h were used in plastic trays of $12-24$ wells and kept at $37{ }^{\circ} \mathrm{C}$ in a $5 \% \mathrm{CO}_{2}$ atmosphere. The inoculum was prepared from brains of Swiss albino mice infected with the strains involved in the study with $10 \% \mathrm{P} / \mathrm{V}$ in (MEM) plus $10 \%$ of FCS and gentamicine. The brains were harvested $48 \mathrm{~h}$ post-infection, grinded and suspended 10\% P/V in MEM, 10\% FCS and gentamicine. Sera were diluted at 1:5 in MEM and those that neutralized the $80 \%$ the plaques forming units (pfu) included in the test were considered positive.

\section{RESULTS}

The results of the antibody prevalence are presented in the Table 1 . The presence of both subtypes IAB and VI of the VEE complex was observed in two surveys conducted.

Only five of the 23 sera collected in May were positive by HI for both subtype, the other 18 were negative. Seven sera assayed by NT were positive for subtypes VI, three sera for the subtypes IAB and three sera had antibodies for both subtypes.

None of the 33 sera from the samples obtained in November were 


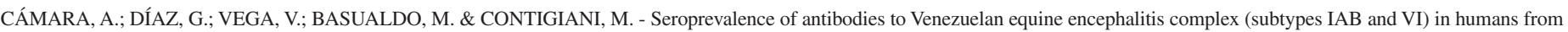
General Belgrano Island, Formosa, Argentina. Rev. Inst. Med. trop. S. Paulo 45(4): 201-204, 2003.

Table 1

Seroprevalence against the virus of the VEE complex in people from the General Belgrano Island, Formosa, Argentina

\begin{tabular}{|c|c|c|c|c|c|c|c|c|}
\hline \multirow{3}{*}{ Viral subtype } & \multicolumn{4}{|c|}{ May 1991 sera } & \multicolumn{4}{|c|}{ November 1991 sera } \\
\hline & $\mathrm{HI}$ & & NT & & $\mathrm{HI}$ & & NT & \\
\hline & $\mathrm{P} / \mathrm{T}$ & $\%$ & $\mathrm{P} / \mathrm{T}$ & $\%$ & $\mathrm{P} / \mathrm{T}$ & $\%$ & $\mathrm{P} / \mathrm{T}$ & $\%$ \\
\hline VI & $0 / 23$ & 0 & $7 / 23$ & 30.4 & $0 / 33$ & 0 & $23 / 33$ & 69.7 \\
\hline IAB & $0 / 23$ & 0 & $3 / 23$ & 13.0 & $0 / 33$ & 0 & $1 / 28$ & 3.6 \\
\hline VI and IAB & $5 / 23$ & 21.7 & $3 / 23$ & 13.0 & $0 / 33$ & 0 & $2 / 28$ & 7.2 \\
\hline
\end{tabular}

HI: Hemagglutination Inhibition Test; NT: Neutralization Test; P/T: positive from total; \%: percent of prevalence.

positive by HI. However, by NT 23 were reactive for subtype VI, one for subtype IAB and two for both.

Among the samples obtained in the two inquires, two sera negative in the 1989 outbreak resulted positives in May (one for each subtype). These samples belonged to a 10 year-old girl infected with subtype IAB (title 1:64) and the other one to a 5 year-old boy with subtype VI (title $1: 256)$.

\section{DISCUSSION}

BETINOTTI in 1957 made the first seroepidemiological studies on the VEE viruses in humans of Argentina. MONATH (1980) reported about the circulation of more than one subtype of the VEE complex in the near zone to Chaco province among host as equines and rodents.

The NT test has the highest specificity for the detection of arbovirus antibodies, and is considered the gold standard reference method (CALISHER et al., 1980). Previous studies using the same test showed that subtype IAB has no antigenic relationship with subtype VI (CÁMARA, 1997).

The studies conducted in General Belgrano Island confirm the activity of the subtypes I and VI of the VEE complex in humans; as a result there are persons which were infected with only one subtype and others with both. This finding in humans agrees with the results informed by CONTIGIANI et al., 1993; although must be interpreted cautiously since clinical observations were incomplete (SABATTINI et al., 1998).

According to our results, the prevalence of antibodies, during this study was highest for the subtype VI (NT), while there were not detected cases by HI for each subtype by separate, but only the prevalence by $\mathrm{HI}$ for both subtypes together was observed. Although, there were few common samples between the 1989 outbreak and May 1991 surveys, two sera became positive, suggesting the circulation of both subtypes. Subtype VI circulation and the higher prevalence for this virus in the studied period suggests that the activity of this subtype presents with peaks of higher presence, while was lower activity of subtype IAB, that maintain cryptic or silent state.

The analysis of these results indicates that there is circulation of both subtypes and that generating the best genetic conditions for the recombination of strains, which may emerge as more aggressive or virulent (epizootic or not) that would lead to new epidemics when better biological conditions are given. This intrinsic behavior, from the genetic point of view, could explain why the separation line between the enzootic and epizootic subtypes results very indefinite, from an epidemiological focus.

We must also consider the factor of the alterations of the ecosystem that are produced naturally or those that are man-made as a result of socioeconomic changes.

In this study we showed that the circulation of both subtypes of VEE, but most importantly, new infections on the outside of outbreaks, showing the need of maintaining continuous studies to know the behavior of these subtypes in our area.

\section{RESUMO}

Estudo da soroprevalência de anticorpos para o vírus do complexo encefalite equina venezuelana (EEV) (subtipos IAB e VI) em humanos da Ilha General Belgrano, Formosa, Argentina

Este trabalho apresenta os resultados da detecção de anticorpos (imunoglobulina G) para os subtipos I e VI dos vírus do complexo EEV (Familia Togaviridae) em população da Ilha General Belgrano, província de Formosa (Argentina). A prevalência de anticorpos neutralizantes para o subtipo VI foi de $30 \%$ a $70 \%$ na primeira e segunda pesquisa respectivamente, e por inibição de hemaglutinação $(\mathrm{IH})$ de $0 \%$. Para o subtipo IAB, a prevalência foi de $13 \%$ a $3,6 \%$ por NT, enquanto anticorpos IH não foram detectados nas duas pesquisas. Observou-se que ambos subtipos circularam simultaneamente, mas enquanto o subtipo VI manteve-se constante com alguns picos de maior presença, o subtipo IAB foi encontrado em nível baixo.

\section{ACKNOWLEDGEMENTS}

We thank Mr. R. Farías for help in the field work and Dr. Sergio Grutadauria for revising this manuscript in English. This study was supported by grants from SECyT, UNC, Argentina.

\section{REFERENCES}

1. BERGE, T.O.; BANKS, I.S. \& TIGERTT, W.D. - Attenuation of Venezuelan equine encephalomyelitis virus by in vitro cultivation in guinea pig-heart cells. Amer. J. Hyg., 73: 209-218, 1961

2. BETTINOTTI, C.M. - Incidencia de anticuerpos fijadores de complemento para virus de encefalitis (cuatro especies diferentes) en la población general de Córdoba. Buenos Aires. Sem. méd. (B. Aires), 110: 393-409, 1957. 


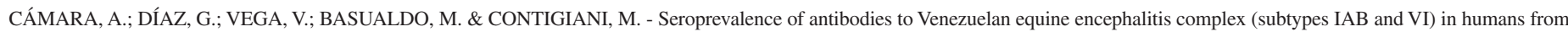
General Belgrano Island, Formosa, Argentina. Rev. Inst. Med. trop. S. Paulo 45(4): 201-204, 2003.

3. CALISHER, C.H. - Medically important arboviruses of the United States and Canadá. Clin. Microbiol. Rev., 7: 89-116, 1994

4. CALISHER, C.H. \& KARABATSOS, N. - Arbovirus serogroups: definition and geographic distribution. In: MONATH, T.P., ed. The Arboviruses: epidemiology and ecology. Boca Ratón, CRC Press, 1988. v. 1, p. 19-57.

5. CALISHER, C.H.; MONATH, T.P.; MITCHELL, C.J. et al. - Arbovirus investigations in Argentina, 1977-80. III. Identification and characterization of viruses isolated, including new subtypes of western and Venezuelan equine encephalitis viruses and four new bunyaviruses (Las Maloyas, Resistencia, Barranqueras and Antequera). Amer. J. trop. Med. Hyg., 34: 956-965, 1985.

6. CALISHER, C.H.; SHOPE, R.E.; BRANDT, W. et al. - Proposed antigenic classification of registered arboviruses. I. Togaviridae, Alphavirus. Intervirology, 14: 229-232, 1980.

7. CAMARA, A. - Encefalitis equina venezolana. Estudios comparativos seroepidemiológicos, biológicos y antigénicos de dos cepas enzoóticas de subtipo VI. Córdoba, 1997. (Tesis Doctoral - Facultad de Ciencias Exactas, Físicas y Naturales/ Universidad Nacional de Córdoba, Argentina).

8. CLARKE, D.H. \& CASALS, J. - Techniques for hemagglutination and hemagglutination inhibition with arthropod-borne viruses. Amer. J. trop. Med. Hyg., 7: 561-573, 1958.

9. CONTIGIANI, M.S. - Togaviridae. In: COTO, C.E.; BASUALDO, J.A. \& de TORRES, R.A. Virología. Microbiología biomédica. Buenos Aires, Editorial Atlante, 1996. p. 726-735.

10. CONTIGIANi, M.S.; DE BASUALDO, M.; CÁMARA, A. et al. - Presencia de anticuerpos contra el virus de la EEV subtipoVI en pacientes con enfermedad aguda febril. Rev. argent. Microbiol., 25: 212-220, 1993.

11. EARLY, E.; PERALTA, P.H. \& JOHNSON, K.M. - A plaque neutralization method for Arbovirus. Proc. Soc. exp. Biol. Med., 25: 741-747, 1967.

12. EHRENKRANZ, N.J. \& VENTURA, A.K. - Venezuelan equine encephalitis virus infection in man. Ann. Rev. Med., 25: 9-14, 1974.

13. IVERSSON, L.B.; TRAVASSOS DA ROSA, A.P.A.; RODRIGUES, S.G. \& ROSA, M.D.B. - Human disease caused by VEE subtype IF in Ribeira Valley, São Paulo, Brazil. In: ANNUAL MEETING OF THE AMERICAN SOCIETY OF TROPICAL MEDICINE AND HYGIENE, 39, New Orleans, 1990. Abstracts. p. 143.
14. MITCHELL, C.J.; MONATH, T.P.; SABATTINI, M.S. et al. - Arbovirus investigations in Argentina, 1977-1980. II. Arthropod collections and virus isolations from Argentine mosquitoes. Amer. J. trop. Med. Hyg., 34: 945-955, 1985.

15. MONATH, T.P. - Epidemiology. Washington, American Public Health Association, 1980 p. 239-312.

16. OBERSTE, M.S.; FRAIRE, M.; NAVARRO, R. et al. - Association of Venezuelan equine encephalitis virus subtype IE with two equine epizootic in Mexico. Amer. J. trop. Med. Hyg., 59: 100-107, 1998.

17. RAMÍREZ, H.; MEJÍA, W. \& ROJAS, E. - Indicadores del estado de la salud. Medellín, Fac. Nac. Salud Pública, Módulo 2, Unidad 3, 1990. p. 80-109.

18. RIVERA, E.; RUIZ, L.; MOSQUERA, O. et al. - Informe técnico sobre las accione realizadas para impedir la propagación del brote de encefalitis equina venezolana al Estado de Lara, proveniente de las Entidades Falcón y Yaracuy. Barquisimeto, Venezuela, Sept. 4, 1995. Apud: Brote de encefalitis equina venezolana, 1995. Bol. epidem. Org. panamer. Salud, 16(4): 9-13, 1995

19. SABATTINI, M.S.; MONATH, T.P.; MITCHELL, C.J. et al. - Arbovirus investigations in Argentina 1977-1980. I. Historical aspects and description of study sites. Amer. J. trop. Med. Hyg., 34: 937-944, 1985.

20. SABATTINI, M.S.; AVILÉ, G. \& MONATH, T.P. - Historical, epidemiological and ecological aspects of arboviruses in Argentina: Flaviviridae, Bunyaviridae and Rhabdoviridae. In: TRAVASSOS DA ROSA, A.P.A.; VASCONCELOS, P.F.C. \& TRAVASSOS DA ROSA, J.F.S., ed. An overview of arbovirology in Brazil and neighbouring countries. Belém, Instituto Evandro Chagas, 1998. p. 113-134.

21. TIKASINGH, E.S.; SPENCE, L. \& DOWNS, W.G. - The use of adjuvant and sarcoma 180 cells in the production of mouse hyperimmune ascitic fluids to arboviruses. Amer. J. trop. Med. Hyg., 15: 219-226, 1966.

22. WEAVER, S.C. - Recurrent emergence of Venezuelan equine encephalomyelitis. In: SCHELD, W.M. \& HUGHES, J., ed. Emerging infectious diseases. Washington, ASM Press, 1998. p. 27-42.

23. WORK, T.H. - Serologic evidence of arbovirus infection in Seminole Indians of southern Florida. Science, 145: 270-272, 1964.

Received: 07 November 2000

Accepted: 10 June 2003 